\title{
Reproductive toxicity of 4-octylphenol induced mitochondria-mediated apoptosis in male mouse- specific niche cells
}

\author{
Mingtian Zhang ${ }^{1,+}$, Hyun Jung Park ${ }^{1,+}$, Kwonho Hong ${ }^{1,}$, Chankyu Park ${ }^{1,}$, Hyuk Song ${ }^{1,}$, \\ 1 Department of Stem Cell and Regenerative Biology, Konkuk University, 1 Hwayang-dong, Gwangjin-gu, Seoul \\ 05029, Republic of Korea \\ † These authors contributed equally to this work \\ ${ }^{*}$ Correspondence: Prof. Hyuk Song, Department of Stem Cell and Regenerative Technology, Konkuk \\ University, 1 Hwayang-dong, Gwangjin-gu, Seoul 05029, Republic of Korea; Tel: +82-2-450-0562; e-mail: \\ songh@konkuk.ac.kr
}

\begin{abstract}
The toxic effects of 4-octylphenol (4-OP) have been studied in species such as mouse and fish; however, the toxic effects of 4-OP in male specific niche cells has not been researched. In this study, we investigated the molecular mechanism of toxicity of 4-OP in mouse TM4 Sertoli cells. TM4 cells were treated with four concentrations $(0,10,30$, and $50 \mu \mathrm{M} / \mathrm{mL}$ ) of $4-\mathrm{OP}$ at time points 24,48 , and $72 \mathrm{~h}$. Cell viability and apoptosis assay was conducted following exposure. 4-OP significantly decreased cell viability in a concentration- and time-dependent manner, and increased apoptosis. Quantitative PCR analysis showed that Bad, Bax, and Bak mRNA expression levels were higher in exposed cells than in the control, but Bcl-2 expression was decreased. Western blotting revealed that 4-OP induced activities of caspase- 3 and phosphorylation of Bad in a concentration- and time-dependent manner. Additionally, cytochrome $\mathrm{C}$ protein did not colocalize with mitochondria marker dye by $24 \mathrm{~h}$. Cytochrome c protein expression increased in a time-dependent manner with $50 \mu \mathrm{M} / \mathrm{mL}$. These results suggest that 4 -OP induces mitochondria-mediated apoptosis by regulation of Bcl-2 family proteins and caspase- 3 activation in male Sertoli cells.
\end{abstract}

Keywords: 4-octylphenol, Male Sertoli cells, Reproductive toxicity, Apoptosis, Mitochondria 


\section{Introduction}

4-Octylphenol (4-OP), one of many long-chain alkylphenols (APs), has been reported to cause environmental contamination through its use by industries worldwide to optimize the manufacturing of common products such as lubricants, plastics, cosmetics, and detergents [1]. APs are accumulated in the human body via ingestion, inhalation, and dermal absorption, and have even been found in maternal blood plasma, amniotic fluid [2], and breast milk [3].

Several studies have reported that 4-OP is a typical endocrine disruptor with estrogenic action, and environmental exposure to endocrine disrupting chemicals (EDCs) has adverse effects on the human reproductive system [4]. It has been reported that long-term 4-tert-octylphenol (OP) exposure in bank voles resulted from disturbed androgen and estrogen synthesis and action (20850518). In addition, a study of mice leydig cells exposed to 4-OP showed a decrease in the secretion of dehydropiandrosterone, androstenedione, and testosterone, and reactive oxygen species overproduction [5]. Similarly, juvenile mouse exposure to OP inhibited steroidogenesis by decreasing the expression of steroidogenic enzymes in the testes [6]. Subcutaneous injections of $80 \mathrm{mg}$ OP in an oil vehicle 3 times weekly decreased sperm production in adult male rats [7], and the number of mitotic germ cells and pre-spermatogonia was reduced in human fetal gonads during a 3-week culture period with 4-OP treatment [8]. In females, the proliferation of uterine luminal, glandular, and stromal cells, and vaginal epithelial cells were increased in adult ovariectomized rats following subcutaneous injection of OP [9].

Fetal exposure to the weak estrogenicity of OP enhanced the induction of mammary carcinomas in rats [10]. Early neonatal exposure to $4-\mathrm{OP}(50 \mathrm{mg} / \mathrm{kg})$ by oral gavage caused delayed sexual maturation and deceased ventral prostate weight [11].

Apoptosis is a common form of programmed cell death that causes morphological changes including cell shrinkage, nuclear fragmentation, and chromatin condensation [12]. Cellular apoptosis is regulated by two typical activation mechanisms: the intrinsic pathway and the extrinsic pathway [13]. Apoptosis via the intrinsic pathway can be induced by the release of cytochrome $\mathrm{c}$ from mitochondria and a change in the level of pro-apoptotic Bcl-2 family proteins such as Bax [14]. Among APs, 4nonylphenol induced thymocyte apoptosis via the intrinsic pathway, including caspase-3 activation and mitochondrial depolarization [15]. It is well-known that Sertoli cells are necessary for the progression of germ cells into sperm in male testes. The damage of Sertoli cells caused by environmental toxicants can negatively affect spermatogenesis.

Although many studies have reported the toxic effects of OP in reproductive organs and various cells, the molecular mechanism of 4-OP in the niche of male germ cells has not been studied in detail. Therefore, the present study examined the molecular mechanism underlying 4-OP mediated toxic effects in TM4 sertoli cells.

\section{Results}

\subsection{Effect of 4-OP on viability of TM4 cells}

Figure 1A illustrates the chemical structure of 4-OP. We determined the cytotoxic effects of 4-OP on the cell proliferation of TM4 sertoli cells. MTT assay was done at 24, 48, and $72 \mathrm{~h}$. TM4 cells were treated with the concentrations of $4-\mathrm{OP}(10,30,50$, and $100 \mu \mathrm{M} / \mathrm{mL})$. As shown in Figure $1 \mathrm{~B}$, cell viability significantly decreased when cells were exposed to the lowest concentration of $4-\mathrm{OP}(10 \mu \mathrm{M} / \mathrm{mL})$ for 72 $h$, although cell viability was only slightly affected when the cells were exposed to the same amount for 24 and $48 \mathrm{~h}$. Notably, marked decrease in cell viability was observed following incubation with 4-OP at concentrations of 30 and $50 \mu \mathrm{M} / \mathrm{mL}$ at 24,48 , and $72 \mathrm{~h}$ (Fig. 1B). The morphological change observed 72 $\mathrm{h}$ after treatment was dose dependent. 4-OP induced dose-dependent apoptotic cell death on TM4 cells. Cell shrinkage and cytoplasm condensation appeared in 30 and $50 \mu \mathrm{M} / \mathrm{mL}$ of 4 -OP treatment (Fig. 1C). 
A

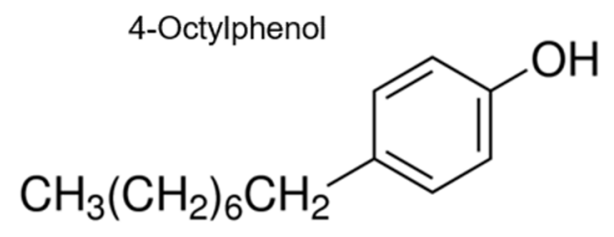

B

TM4 cells

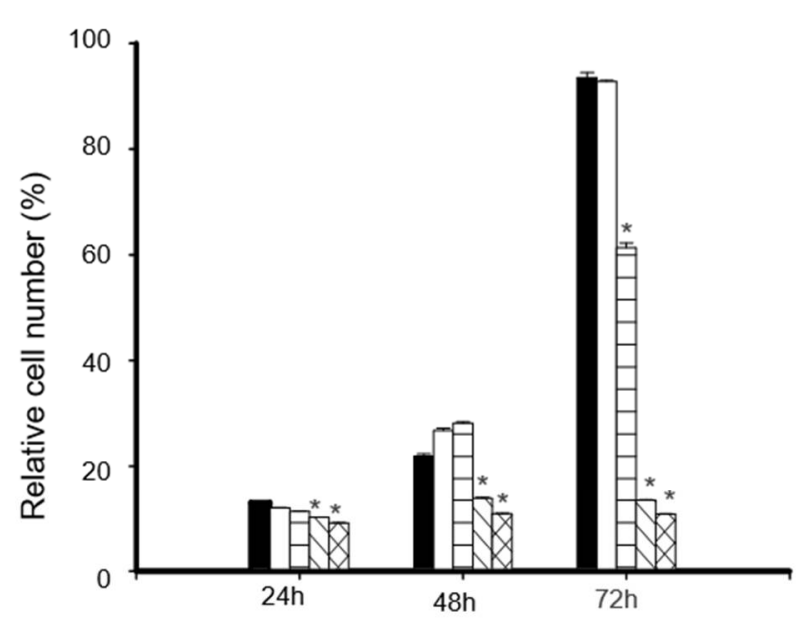

C
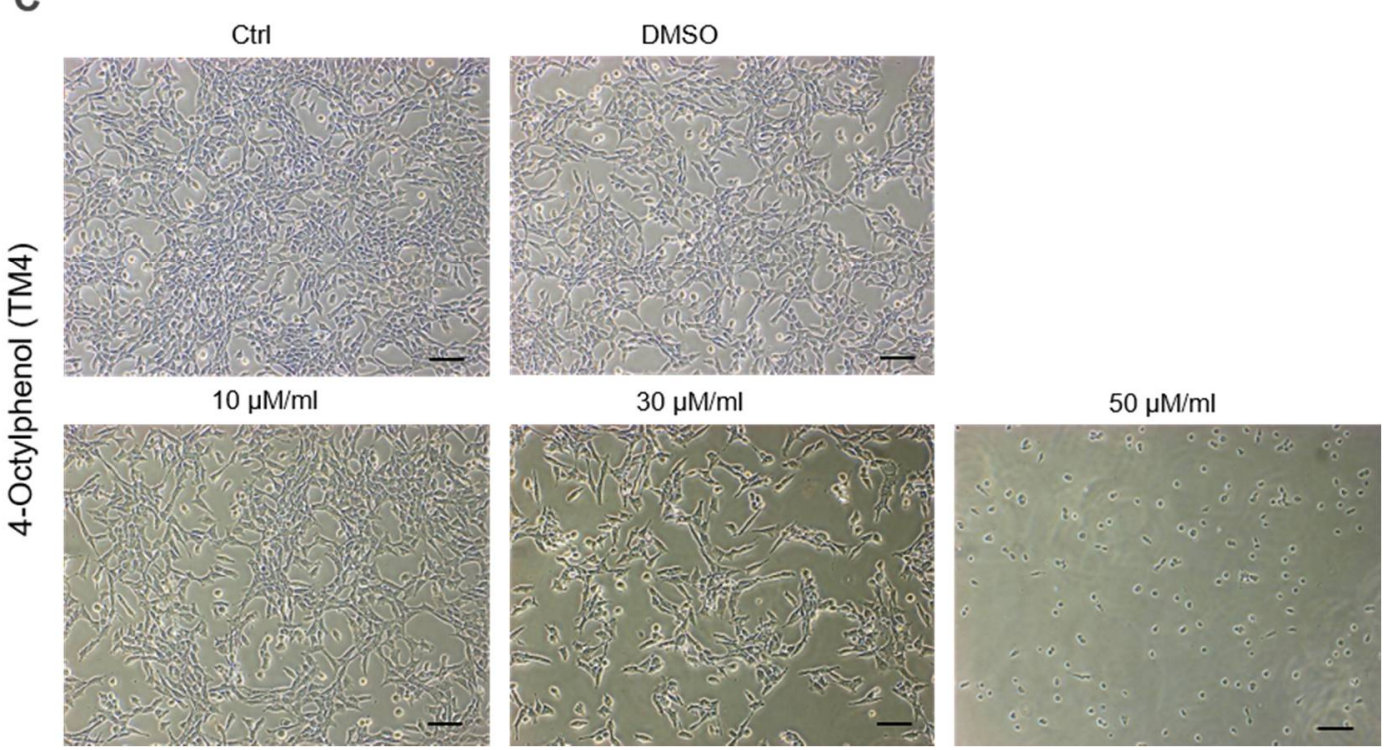

Figure 1. Cytotoxic effects of 4-OP on mouse TM4 Sertoli cells. (A) Chemical structure of 4-OP after treated with increasing doses of $4-\mathrm{OP}(0,10,30$, and $50 \mu \mathrm{M} / \mathrm{mL})$ at different time points $(24,48$, and 72 h), (B) TM4 cell viability was measured by MTT assay. Results are represented as mean \pm SD from 3 determinations per condition repeated 4 times. $\mathrm{P}<0.05$, compared with the control. (C) Morphological changes of TM4 cells were photographed under an inverted microscope after treatment with indicated concentration of $4-\mathrm{OP}(0,10,30$, and $50 \mu \mathrm{M} / \mathrm{mL})$ for $72 \mathrm{~h}$. Scale bars $=100 \mu \mathrm{m}$. 


\subsection{Effects of 4- OP on apoptosis of TM4 cells}

Cell apoptosis was examined using a TUNEL assay to quantify cellular death. As shown in Figure 3, 4-OP significantly increased the number of TUNEL-positive cells in a dose-dependent manner $(0,30$, and $50 \mu \mathrm{M} / \mathrm{mL}$ ). In particular, 30 and $50 \mu \mathrm{M} / \mathrm{mL}$ of 4-OP markedly increased TUNEL-positive TM4 cells (Fig. 2A). The data indicated that TUNEL-positive rates of TM4 and control were $13.95 \pm 0.14$ and 53.29 \pm 1.13 , respectively (Fig. 2B).

A
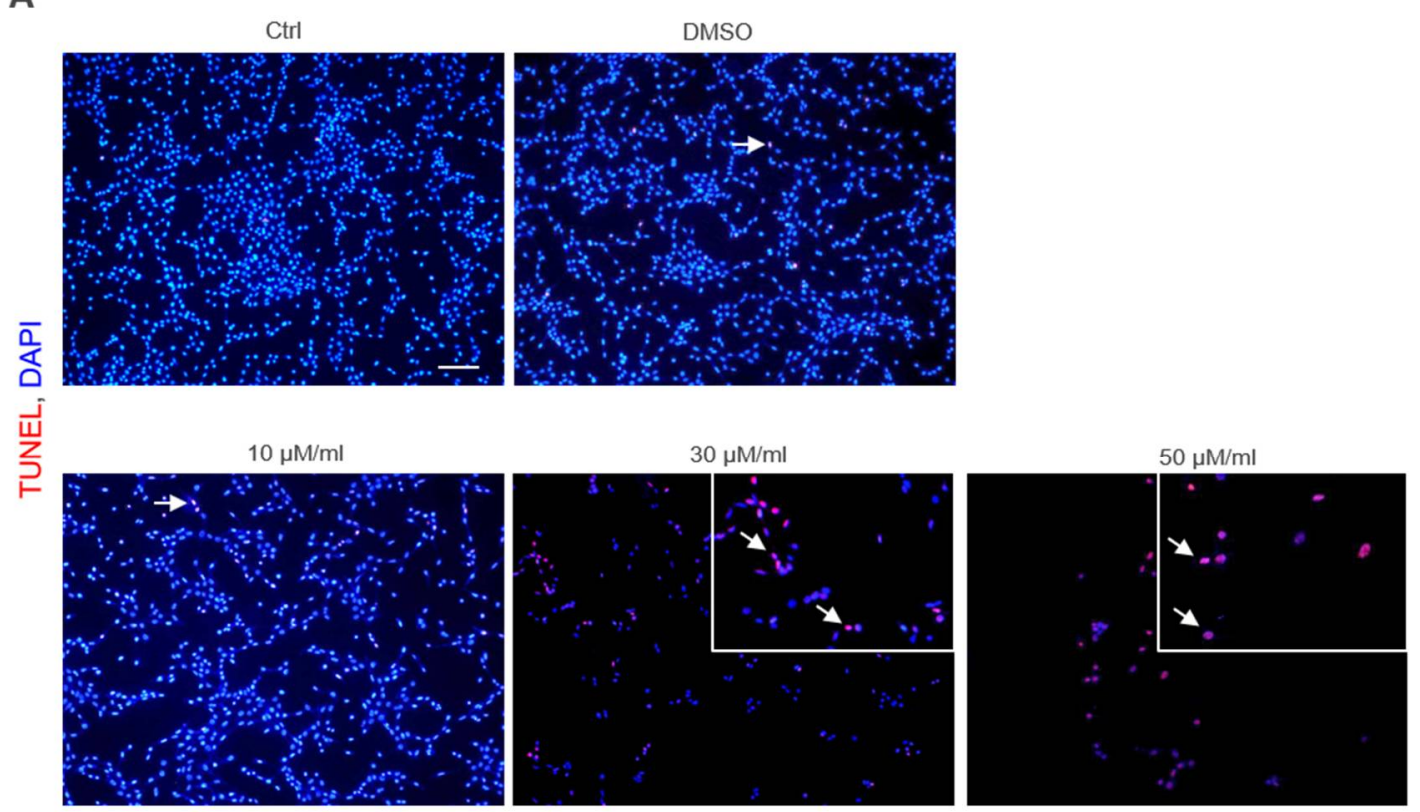

B

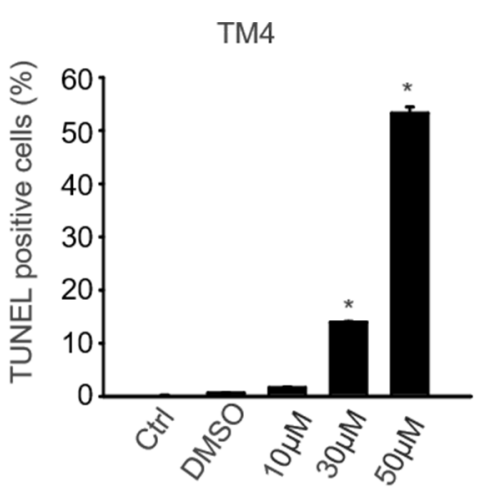

Figure 2. 4-OP-induced cell death in the TM4 cells by TUNEL assay. (A) Detection of in situ DNA breaks by TUNEL assay. Cells were exposed to $0,10,30$, and $50 \mu \mathrm{M} / \mathrm{mL}$ 4-OP for $24 \mathrm{~h}$, the TUNEL positive cells (arrow) increased dose-dependently in the 4-OP-treated TM4 cells. Bar represents $100 \mu \mathrm{m}$. (B) Graph representing average number of TUNEL-positive cells in each group. The percentage of TUNEL positive cells in each case were counted and the cumulative data from 3 independent experiments in shown here as mean $\pm S D\left(n=3,{ }^{*} p<0.05\right.$ significantly different from control). 


\subsection{4-OP induces the expression of pro-apoptotic gene and protein TM4 cells}

To understand the apoptotic effect of 4-OP signaling in detail, we further analyzed several apoptosis-associated molecules. The expression levels of Bax, Bad, Bcl-2, and Bak, mRNAs that play essential roles in modulating apoptosis, were analyzed. Bax, Bad, and Bak mRNA levels in TM4 ells treated with 4-OP increased in dose-dependent manner (Fig. 3). Bad and Bax mRNA levels in TM4 cells treated with 4-OP increased in a dose-dependent manner (Fig. 3A and B). In addition, the expression level of Bak significantly increased in TM4 cells treated with $50 \mu \mathrm{M} / \mathrm{mL}$ of 4-OP, when compared with the control, and decreased Bcl-2 levels were observed in TM4 cells treated with 30 and $50 \mu \mathrm{M} / \mathrm{mL}$ of $4-\mathrm{OP}$ (Fig. 3C and D). Since caspase-3 activation is considered a hallmark of the apoptotic process, activation of caspase-3 by 4-OP was confirmed by western blot analysis to confirm whether pro-apoptotic protein is involved in this apoptosis induction (Fig. 4). Caspase-3 activity was significantly increased in 4-OP exposed TM4 cells in a dose-dependent manner (Fig. 4A). Consistently, $50 \mu \mathrm{M}$ of 4-OP treatment increased the level of cleaved caspase-3, the active form of caspase-3, in TM4 cells $24 \mathrm{~h}$ after treatment, but total caspase-3 was not elevated at all time points when compared with the $0 \mathrm{~h}$ control (Fig. 4B). Based on our QPCR result, we examined the effect of 4-OP on the phosphorylation of Bad and found remarkable detection of Bad phosphorylation in TM4 cells after exposure to 4-OP in a dose-dependent manner (Fig. 4C). We found that $50 \mu \mathrm{M} / \mathrm{mL} 4-\mathrm{OP}$ also induced Bad phosphorylation of TM4 cells at 24 and $48 \mathrm{~h}$, when compared with the control (Fig. 4D). For normalization, total Bad protein levels were determined with Bad antibody, which reacted with both the phosphorylated and non-phosphorylated Bad. 
A

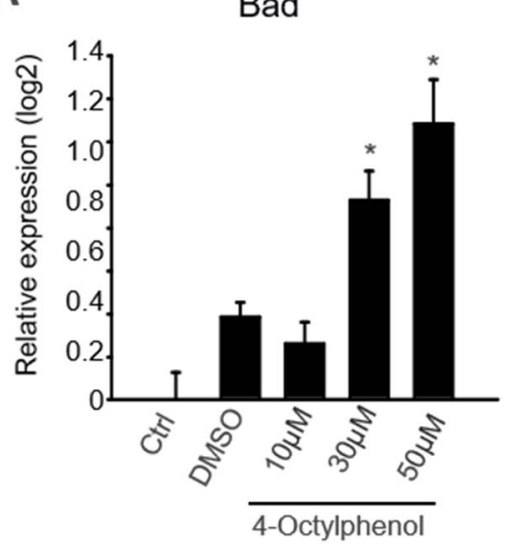

C

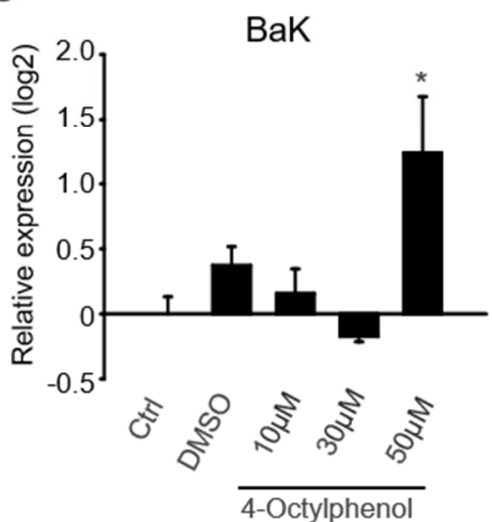

B

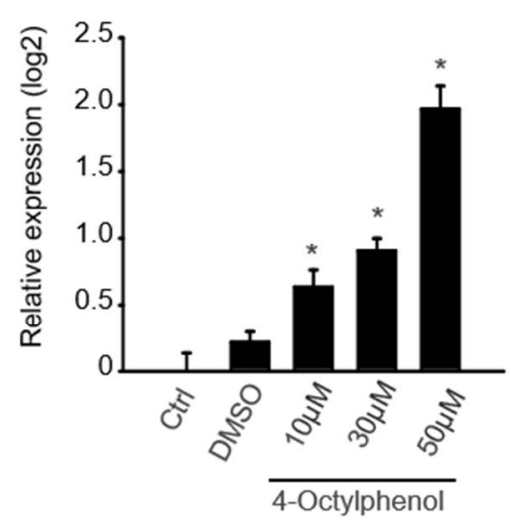

D

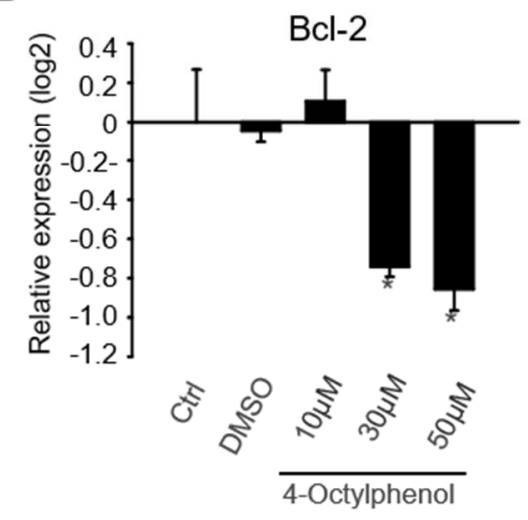

Figure 3. mRNA expression of anti-and pro-apoptotic genes in 4-OP-exposed TM4 cells. The mRNA levels of Bad (A), Bax (B), Bak (C), and Bcl-2 (D) were examined by QPCR on 4-OP exposed TM4 cells in a dose dependent manner $(0,10,30$, and $50 \mu \mathrm{M} / \mathrm{mL} 4-\mathrm{OP})$. Data shows significant difference of 4-OP exposed cells compared to the control group. Results are represented as mean \pm SD from 3 determinations per condition repeated 4 times. $\left(n=4,{ }^{*} p<0.05\right)$. 
A
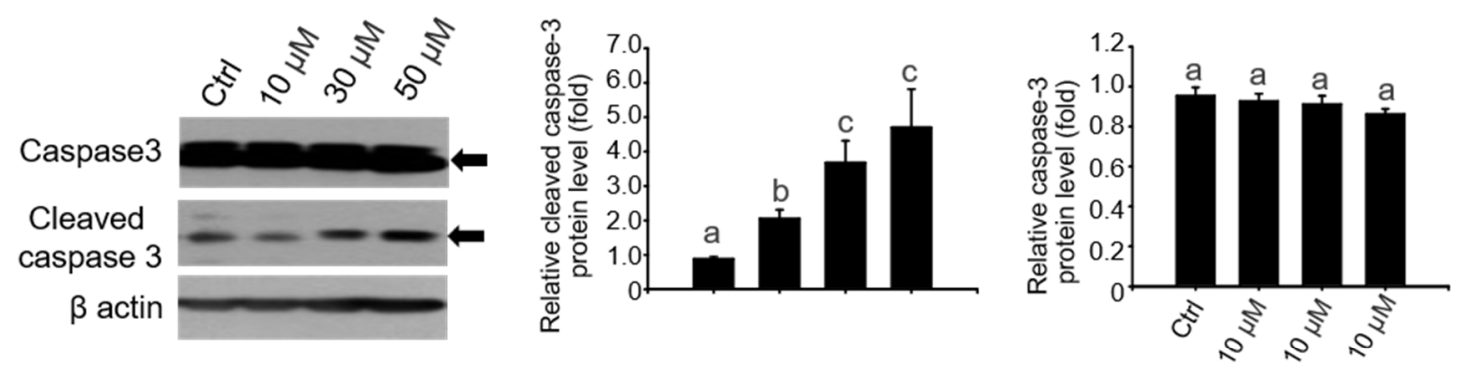

B
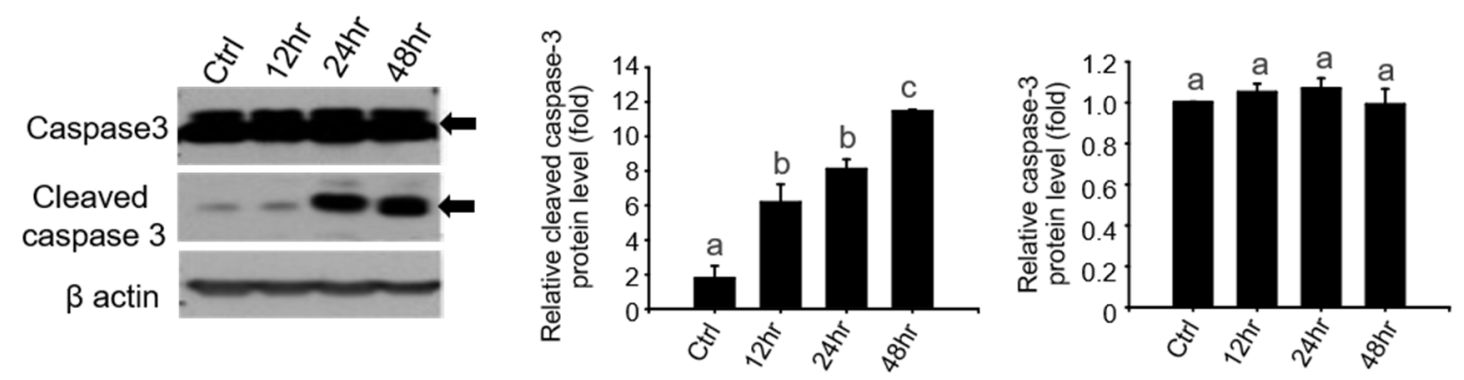

C
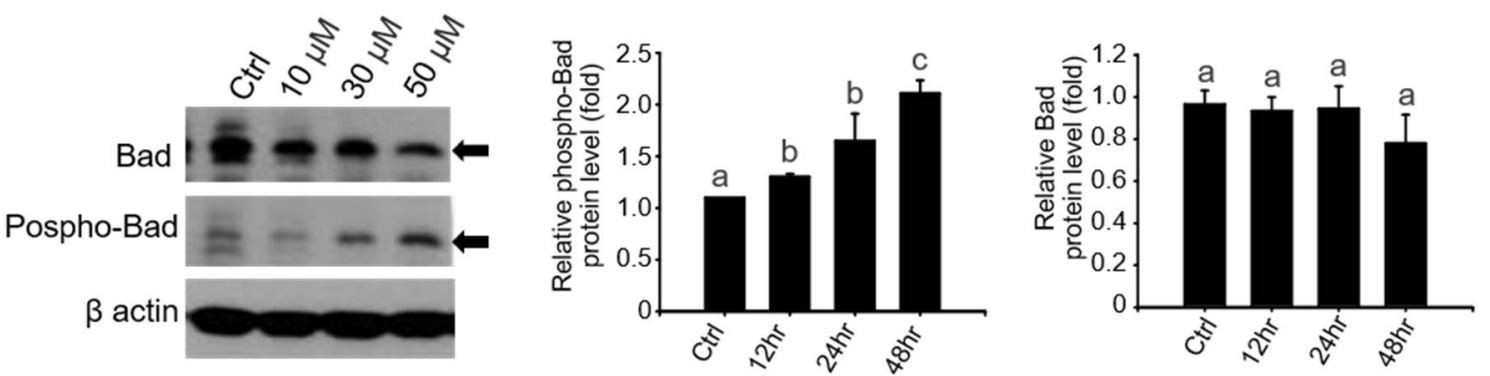

D
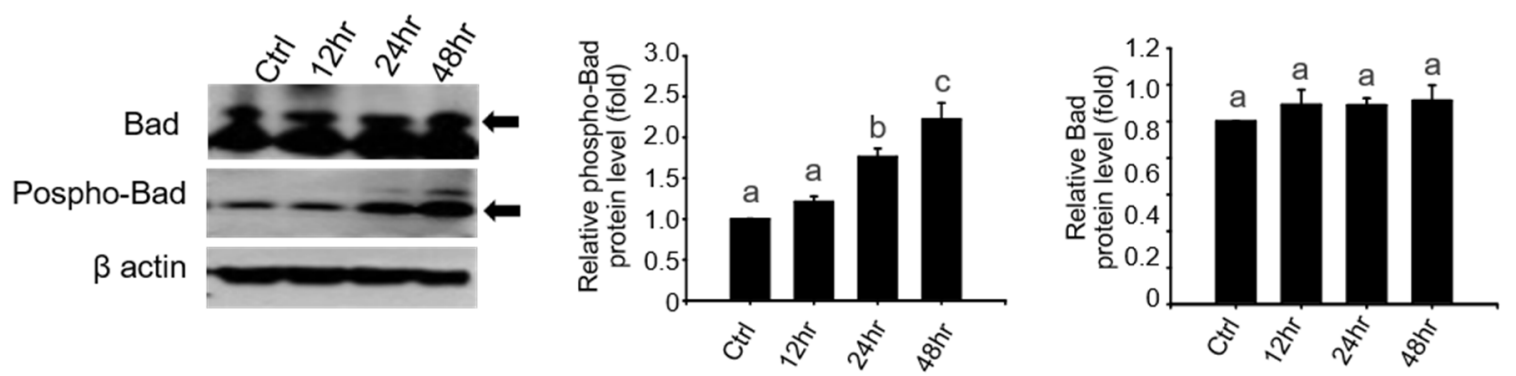

Figure 4. The expression of pro-apoptotic protein in 4-OP-exposed TM4 cells. 4-OP increased the expression of cleaved caspase-3 in 4-OP-exposed TM4 cells. (A) After treatment with different concentrations of 4 -OP $(0,10,30$, and $50 \mu \mathrm{M} / \mathrm{mL})$ for $24 \mathrm{~h}$. (B) TM4 cells were treated with $50 \mu \mathrm{M} / \mathrm{mL}$ $4-\mathrm{OP}$, respectively, at different time points $(0,24$, and $48 \mathrm{~h})$. The expression levels of cleaved caspase-3, caspase-3 and $\beta$-actin were examined by western blot. (C) After treatment with different concentrations $(0,10,30$, and $50 \mu \mathrm{M} / \mathrm{mL})$ for $24 \mathrm{~h}$ and (D) different time points $(0,24$, and $48 \mathrm{~h})$ of 4 -OP. The expression level of phospho-Bad, Bad, and $\beta$-actin were examined by western blot. Bar graphs represent the relative density of each band normalized to $\beta$-actin or the no active form of each protein. Values represent the mean $\pm S D$ of 3 independent experiments $\left(n=3,{ }^{*} p<0.05\right.$ compared with the controls). 


\subsection{4- OP induces cytochrome $\mathrm{c}$ release from mitochondria in TM4 cells}

We determined whether the mitochondria pathway is involved in TM4 apoptosis induced by 4-OP. Generally, cytocrome c release from mitochondria has been proposed to be a critical event that initiates apoptosis in mammals [16]. We examine whether 4-OP induced the release of cytochrome c from mitochondria to the cytosol. The cellular localization of cytochrome c protein was examined by confocal immunofluoresence microscopy in TM4 cells. Labeling was done with MitoTracker, a red fluorescent dye that targets mitochondria. The results showed an apparent difference in the levels of cytochrome $c$ between the treatment and control groups at $24 \mathrm{~h}$ post treatment. The pattern of cytochrome $\mathrm{c}$ immunofluorescence and mitochondrial dye showed complete colocalization in the untreated controls as overlapping red and green pixels seen as yellow in the TM4 cells (Fig. 5A). In contrast, the pattern of staining observed after treatment with 4-OP revealed that mitochondria were stained with red MitoTracker dye but were no longer colocalized with cytochrome c in the TM4 cells (Fig. 5B). In addition, western blot analysis indicated that 4-OP significantly increased the expression level of cytochrome $\mathrm{c}$ (Fig. 5C). 

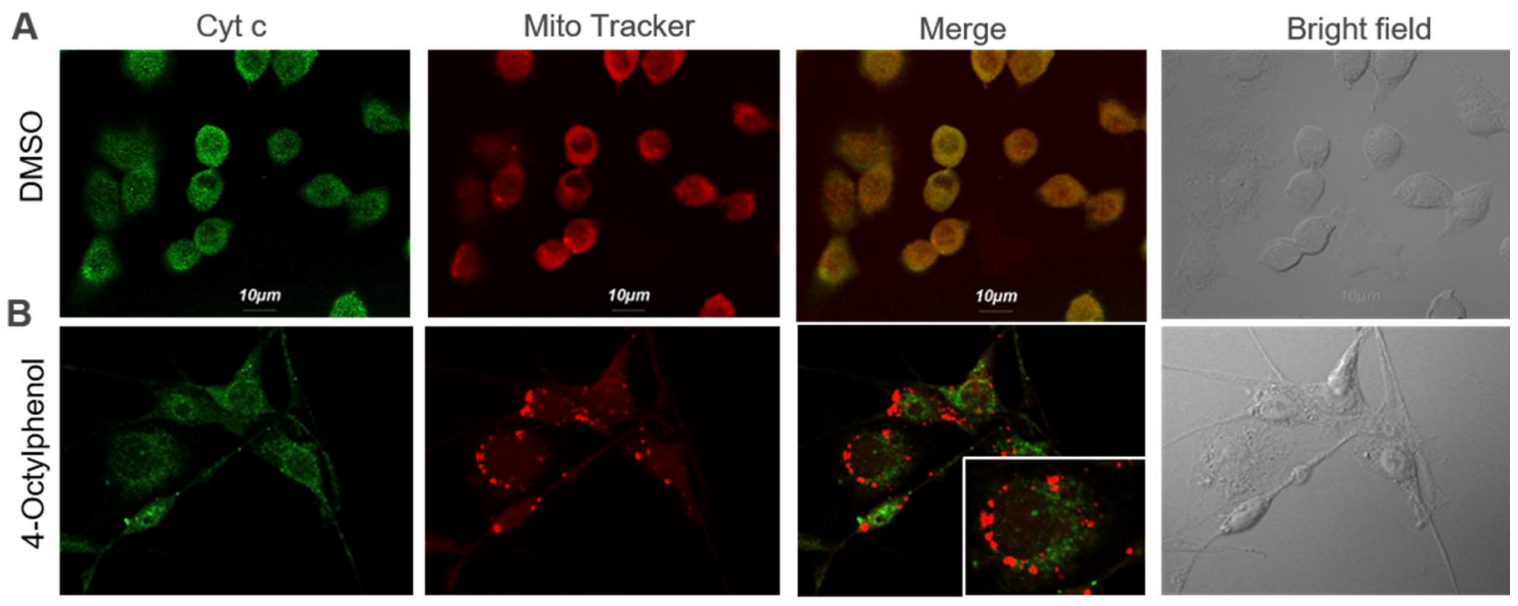

C

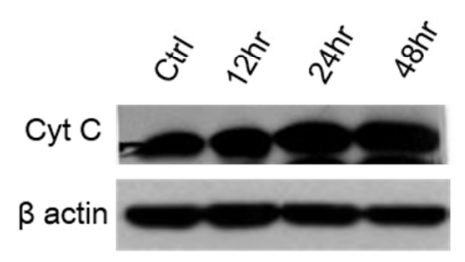

Figure 5. 4-OP induces cytochrome c release in TM4 cells in a time-dependent manner. (A) Effect of 4-OP on cytochrome c expression in TM4 cells. After treatment with $50 \mu \mathrm{M} / \mathrm{mL} 4-\mathrm{OP}$ for $24 \mathrm{~h}$, cells were stained with Mito Tracker red (Mito Red) dye followed by immunostaining for cytochrome c and observed under a confocal microscope. Scale bars $=10 \mu \mathrm{m}$. (B) Cytochrome c was examined by western blot on $50 \mu \mathrm{M} / \mathrm{mL}$ 4-OP-exposed TM4 cells in time-dependent manner $(0,10,30$, and $50 \mu \mathrm{M} / \mathrm{mL})$. Bar graphs represent the relative density of each band normalized to $\beta$-actin. Values represent the mean \pm SD of 3 independent experiments ( $n=3,{ }^{*} p<0.05$ compared with the controls). 


\section{Discussion}

Our results suggested that 4-OP was toxic to TM4 cells. In addition, we found that 4-OP could induce TM4 cell apoptosis, which was verified by TUNEL analysis. Qian et al similarly reported that OP decreased viability and increased apoptosis in concentration- and time-dependent manner in cultured Sertoli cells derived from Sprague-Dawley rats; however, $30 \mu \mathrm{M} / \mathrm{mL}$ OP did not affect the proliferation of Sertoli cells, in contrast to our TM4 cell viability results [17]. Another study reported that OP had a toxic effect on spermatogenic cells or Sertoli cells in rats [18].

4-OP induces apoptosis through various molecular mechanisms, such as the induction of apoptotic proteins and gene expression. There is much research showing that the Bcl-2 family plays an important role in the regulation of both pro- and anti-apoptotic signals in healthy and stressed cells. Antiapoptosis proteins in the Bcl-2 family include $\mathrm{Bcl}-\mathrm{X}_{\mathrm{L}}, \mathrm{BCL}-\mathrm{W}$, and $\mathrm{Bcl}-2$, and these proteins appear to directly or indirectly preserve the integrity of the outer mitochondrial membrane, thereby preventing cytochrome c release and cell death initiation. In contrast, Bax, Bak, and Bad are pro-apoptotic proteins that mediate mitochondrial outer membrane permeabilization (MOMP) during apoptosis [19, 20].

In this study, Bad, Bax, and Bak gene expression was markedly higher in 4-OP-exposed TM4 cells than in the control group. Results also showed that 4-OP induced activities of caspase-3 and phosphorylation of Bad in TM4 cells. These findings not only help us understand the anti-proliferation and apoptosis effect of 4-OP, but also improve our understanding of apoptotic signaling pathways. According to previous research, caspases are crucial mediators of apoptosis. In particular, caspase-3 has been extensively studied as a protease that activates cell death, catalyzing the specific cleavage of many proteins, and is dependent on mitochondria cytochrome c release function [20]. Caspase-3 is indispensable for apoptotic chromatin condensation and DNA fragmentation in all cell types investigated. In addition, a previous study showed Bcl-2, Bax, and caspase-3 activation were involved in the regulation of the PO-induced apoptotic process in cultured rat Sertoli cells, supporting our results [16].

Generally, mitochondria play a key role in mediating apoptosis induction by diverse stimuli. The release of cytochrome $\mathrm{c}$ from mitochondria and downstream caspase activation are important in regulating apoptosis [21, 22]. Bcl-2 family proteins regulate MOMP and it has been reported that Bax and Bak are also essential for MOMP and both Bax and Bak deficient cells are resistant to cytochrome $c$ release and apoptosis [23]. We found that Bax and Bak expression was increased in TM4 cells with 4OP treatment; thus, we analyzed the cytochrome $\mathrm{c}$ in these cells and found that cytochrome c protein does not colocalize with mitochondria marker dye in exposed cells $24 \mathrm{~h}$ after treatment. In addition, cytochrome c protein increased in a time-dependent manner in $50 \mu \mathrm{M} / \mathrm{mL}$ 4-OP-exposed cells.

$4-\mathrm{OP}$ is one of many alkylphenol compounds and is a known an environmental pollutant. Moreover, it is a known EDC with estrogenic effects [24]. Multiple studies have shown the impact of 4-OP in the reproductive systems of different species such as frog [25], swine [26], fish [27, 28], and rodent [5, 29].

Even though Gregory et al. demonstrated that OP treatment of adult rats does not appear to have a major effect on the male reproductive system at a relevant environmental exposure dose [30], many studies have reported the negative effects of 4-OP in testes or testicular cells. In rodent testes, OP appears to inhibit cAMP formation and steroidogenesis in mLTC-1 leydig tumor cells [31]. In addition, 4-OP induced reproductive abnormalities including small testes weight and decreased daily sperm production [32]. Another study reported that administration of $80 \mathrm{mg} / \mathrm{kg}$ OP to adult male rats caused shrinkage of the testes and accessory sex organs, and disrupted spermatogenesis. In humans, 4-OP significantly reduced the mitotic index and the number of pre-spermatogonia in cultured fetal gonads [8].

The seminiferous tubules in testes are composed of two major cell types, spermatogenic cells and Sertoli cells. It is well-known that Sertoli cells normally control germ cell apoptosis and spermatogenesis, and facilitate the progression of germ cells to spermatozoa through direct contact in seminiferous tubules [33]. For example, Mono-(2-ethylhexyl) phthalate (MEHP), the active metabolite 
of di-(2-ethylhexyl) phthalate, targets Sertoli cells and makes them dysfunctional, resulting in the rapid induction of testicular germ cell apoptosis [34]. In addition, several models of Sertoli cell injury showed that spermatogenesis is vulnerable to disruption and that targeting critical Sertoli cell functions can lead to rapid and massive germ cell death [35]. Therefore, the apoptosis of Sertoli cells may result from the abnormal effect of 4-OP. Maternal exposure to OP suppressed gonadotropin secretion with decrease in testis size and Sertoli cell number during the fetal life of lamb but there was no effect to development of the reproductive tract in male or female rats, although body weights were significantly decreased [10]. Toxicity of OP has been extensively investigated in other organs as well. For example, OP induced splenocyte apoptosis in rats and mice through Ca2+-dependence [36] and OP also had toxic effects on liver in male rats [37]. Therefore, toxicity evaluation of 4-OP in TM4 Sertoli cells is needed to ensure normal sperm production in humans and animals.

In summary, our data suggest that 4-OP-induced TM4 cell apoptosis occurs in a time- and dosedependent manner directly through the mitochondrial apoptotic pathway. Of particular importance is that high dose of 4-OP induced TM4 apoptosis via the down-regulation of Bcl-2; in contrast, Bak, Bad, Bax expression was upregulated with subsequent activation of the caspase- 3 pathway. These findings can contribute to understanding the mechanism of 4-OP on the male reproductive system through its action on the TM4 Sertoli cells.

\section{Materials and Methods}

\subsection{Cell culture and treatment}

Mouse TM4 Sertoli (TM4) cells were purchased from the Korean cell line bank (KCLB 21715, South Korea). The cells were cultured in Dulbecco's Modified Eagle's medium, 10\% fetal bovine serum (FBS), and $1 \%$ penicillin streptomycin solution, in a humidified atmosphere of $5 \% \mathrm{CO}_{2}$ at $37{ }^{\circ} \mathrm{C}$. 4 -OP was purchased from Sigma Aldrich (Sigma-aldrich, St. Louis, MO, USA), and dissolved in dimethyl sulfoxide (DMSO) to make a stock solution. The stock solution was diluted into the cell culture media prior to treatment to prepare the desired concentration.

\subsection{Cell viability and morphologic analysis}

Cell viability was determined using the EZ-Cytox Viability assay kit (Daeil Lab Services Co, Seoul, Korea, \#EZ1000) following the manufacturer's instructions. TM4 cells were seeded in 96-well plates at a density of $5 \times 10^{3}$ per well in culture medium and incubated for $24 \mathrm{~h}$ at $37^{\circ} \mathrm{C}$. After $24 \mathrm{~h}$, medium was replaced with fresh medium containing different concentrations of 4-OP $(10,30,50$, or $100 \mu \mathrm{M} / \mathrm{mL})$. Cell viability assay was performed at multiple time points $(24,48$, and $72 \mathrm{~h}$ ). Assay reagent was added $(10 \mu \mathrm{L}$ per well) and incubated for $30 \mathrm{~min}$. The incubated plate was read on a spectrophotometer (Sunrise ${ }^{\mathrm{TM}}, \mathrm{TECAN}$ ) at a wavelength of $490 \mathrm{~nm}$. Cell images were collected for each dose of 4-OP after $72 \mathrm{~h}$.

\subsection{Apoptosis detection with TUNEL assay}

To evaluate cell death by apoptosis, an in situ cell death detection kit, TMR red (Roche, Germany), was used to quantify DNA and chromatin morphogenic features. The procedures were followed according to the manufacture's guidelines. Cells were cultured on glass slides for $24 \mathrm{~h}$, then exposed to 4 -OP $(10,30,50$, or $100 \mu \mathrm{M} / \mathrm{mL})$ for $48 \mathrm{~h}$. Cells grown on coverslips were washed twice with PBS (SigmaAldrich) and fixed with $4 \%$ paraformaldehyde in PBS for $60 \mathrm{~min}$ at $24^{\circ} \mathrm{C}$. Following washing with PBS, these cells were incubated in permeabilization solution ( $0.1 \%$ Trition X-100 in $0.1 \%$ sodium citrate) for $2 \mathrm{~min}$ on ice. Samples were incubated in $50 \mu \mathrm{L}$ TUNEL reaction mixture (Roche, Mannheim, Germany) for $60 \mathrm{~min}$ at $37^{\circ} \mathrm{C}$ in a humidified chamber and in the dark. An in situ cell death detection kit provided the negative control (label solution without terminal transferase, Roche) for the assay; and preincubation of cells with $10 \mu \mathrm{g} / \mathrm{mL}$ DNase I in $50 \mathrm{mM}$ Tris- $\mathrm{HCl}$, $\mathrm{pH} 7.4,1 \mathrm{mM} \mathrm{MgCl}$, and $1 \mathrm{mg} / \mathrm{mL}$ 
BSA for $10 \mathrm{~min}$ at room temperature to artificially induce DNA strand breaks served as positive control. Samples were incubated with or without $1 \mu \mathrm{g} / \mathrm{mL}$ 6-diamidino-2-pheylindole (DAPI) in PBS for $10 \mathrm{~min}$ and coverslips were applied with mounting solution (Dako, Carpinteria, CA, USA; S3025) and analyzed under fluorescence microscopy (Nikon, Tokyo, Japan).

\subsection{Isolation of RNA and quantitative PCR}

Total RNA was extracted from TM4 cells using a RNeasy Mini Kit (Qiagen, Hilden, Germany) with on-column DNase treatment (Qiagen). Complementary DNA was synthesized from $1 \mu \mathrm{g}$ of total RNA using SuperScript ${ }^{\mathrm{TM}}$ III Reverse Transcriptase (Invitrogen, Carlsbad, CA, USA) with the Oligo(dT)30 primer according to the manufacturer's instructions. Target gene PCR amplification was carried out for 30 cycles of $30 \mathrm{~s}$ at $95{ }^{\circ} \mathrm{C}, 10 \mathrm{~s}$ at $57{ }^{\circ} \mathrm{C}$, and $20 \mathrm{~s}$ at $72{ }^{\circ} \mathrm{C}$. Primers were designed using Primer3 (http://frodo.wi.mit.edu). The QPCR was achieved using a total volume of $20 \mu \mathrm{L}$, containing $10 \mathrm{ng}$ of cDNA and 1 pM of each primer, in a reaction buffer containing iQ SYBR Green Supermix (170-8880; Bio-Rad Laboratories). The cycle threshold values were normalized against GAPDH gene expression, a denaturation and polymerase activation step at $94^{\circ} \mathrm{C}$ for $1 \mathrm{~min}$ and then 40 cycles consisting of $94^{\circ} \mathrm{C}$ for $10 \mathrm{~s}, 57^{\circ} \mathrm{C}$ for $10 \mathrm{~s}$, and $72{ }^{\circ} \mathrm{C}$ for $20 \mathrm{~s}$. The primers used to detect porcine transcripts are listed in Table 1.

\subsection{Western blot analysis}

Whole cell lysates were prepared using RIPA buffer (Thermo Fisher Scientific \#89900) supplemented with protease inhibitor cocktail (Roche, \#1836153). Protein samples containing equal quantities of protein were subjected to $4 \%$ to $20 \%$ Mini-TGX (Bio-Rad, Hercules, CA, USA; \#456-1096) gel electrophoresis and transferred onto polyvinylidene difluoride membranes. Membrane nonspecific binding was blocked by incubation of the membranes in blocking solution (1\% bovine serum albumin (BSA) in tris buffered saline (TBS)) for $1 \mathrm{~h}$ at $22^{\circ} \mathrm{C}$, and then membranes were incubated overnight at $4{ }^{\circ} \mathrm{C}$ with a primary antibody diluted in TBST $(20 \mathrm{mM}$ Tris- $\mathrm{HCl}$ with $\mathrm{pH} 7.5,150 \mathrm{mM} \mathrm{NaCl}$, and $0.1 \%$ Tween-20). The following primary antibodies were used: phospho-Bad (1:1000 dilution; Cell signaling, \#5284T), Bad (1:1000 dilution; Cell Signaling, \#9239T), caspase-3 (1:1000 dilution; Cell Signaling, \#9665T), cleaved caspase-3 (1:1000 dilution; Cell Signaling, \#9661T), cytocrome c (1:1000 dilution; Abcam, \#ab76107) and $\beta$-actin (1:1000 dilution; Santa Cruz Biotechnology, \#sc47778). Membranes were washed in TBST and incubated for $1 \mathrm{~h}$ with anti-rabbit and anti-mouse IgG and HRP-linked antibody (1:10000 dilutions; Jackson Immuno-Research Laboratories) in TBST. Blots were visualized using Pierce ECL western blotting substrate and HyBlot CL autoradiography film (Denville Scientific, Metuchen, NJ, USA; \# E3018).

\subsection{Immunofluorescence}

TM4 cells were seeded on $12 \mathrm{~mm}$ glass coverslips (BD Biosciences, Franklin Lakes, NJ) at a density of $2 \times 10^{5}$ cells per coverslip and allowed to attach for $1 \mathrm{~d}$ prior to treatment with 10, 30, 50, or 100 $\mu \mathrm{M} / \mathrm{mL}$ of 4 -OP for $24 \mathrm{~h}$. After washing once with cold PBS, cells were fixed with $4 \%$ paraformaldehyde and blocked with $1 \%$ BSA in PBS containing $0.2 \%$ Triton X-100. Samples were subsequently incubated with mouse anti-cytocrome c antibody (Santa Cruz Biotechnology, sc-13156, 1:200) diluted in blocking solution overnight at $4{ }^{\circ} \mathrm{C}$. After washing 3 times, the samples were incubated with secondary antibody (Alexa Fluor 488 anti-mouse IgG; 1:1000) diluted in blocking buffer (1\% BSA in PBS) for $1 \mathrm{~h}$. Then samples were washed once with warm PBS and incubated for $30 \mathrm{~min}$ with $100 \mathrm{nM}$ of MitoTracker ${ }^{\circledR}$ red CMXRos (M7512, Life Technologies, Carlsbad, CA, U S A) and washed 3 times. Nuclei were counterstained with TO-PRO-3 (Life Technologies) and DAPI (Sigma-Aldrich). Samples were mounted with mounting medium (Sigma-Aldrich) and images were taken under a confocal microscope (Carl Zeis, Oberkochen, Germany; LSM 700). 


\subsection{Statistical analysis}

The SPSS statistical package, version 15.0 for Windows (IBM Corp, Somers, NY, USA) was used for data analysis. All the data were expressed as mean \pm standard error. The differences between controls and experimental samples were evaluated by one-way ANOVA, followed by Tukey's honestlysignificant difference test. Significance levels of 0.05 and 0.01 were applied during data analysis using Student's t-test, and different significance levels have been indicated ( $\left.{ }^{*} \mathrm{P}<0.05\right)$. A significance levels of 0.05 was applied during data analysis using ANOVA.

\section{Competing Interests}

The authors declare that they have no competing interests.

\section{Acknowledgements}

This work was supported by the Science Research Center (2015R1A5A1009701) from the National Research Foundation of Korea, Republic of Korea.

\section{Reference}

1. Ying, G.G. Fate, behavior and effects of surfactants and their degradation products in the environment. Environ. Int. 2006, 32, 417-31.

2. Shekhar, S.; Sood, S.; Showkat, S.; Lite, C.; Chandrasekhar, A.; Vairamani, M.; Barathi, S.; Santosh, $\mathrm{W}$. Detection of phenolic endocrine disrupting chemicals (EDCs) from maternal blood plasma and amniotic fluid in Indian population. Gen. Comp. Endocrinol. 2017, 241, 100-107.

3. Ademollo, N.; Ferrara, F.; Delise, M.; Fabietti, F.; Funari, E. Nonylphenol and octylphenol in human breast milk. Environ. Int. 2008, 34, 984-987.

4. Mendis-Handagama, S.M.; Ariyaratne, H.B. Differentiation of the adult Leydig cell population in the postnatal testis. Biol. Reprod. 2001, 65, 660-671.

5. Jambor, T.; Greifova, H.; Kovacik, A.; Kovacikova, E.; Tvrda, E.; Forgacs, Z.; Massanyi, P.; Lukac, N. Parallel. Effect of 4-octylphenol and cyclic adenosine monophosphate (cAMP) alters steroidogenesis, cell viability and ROS production in mice Leydig cells. Chemosphere. 2018, 199, 747-754.

6. Kim, S.K.; Kim, J.H.; Lee, H.J.; Yoon, Y.D. Octylphenol reduces the expressions of steroidogenic enzymes and testosterone production in mouse testis. Environ Toxicol. 2007, 22, 449-458.

7. Boockfor, F.R.; Blake, C.A. Chronic administration of 4-tert-octylphenol to adult male rats causes shrinkage of the testes and male accessory sex organs, disrupts spermatogenesis, and increases the incidence of sperm deformities. Biol. Reprod. 1997, 57, 267-277.

8. Bendsen, E.; Laursen, S.; Olesen, C.; Westergaard, L.; Andersen, C.; Byskov, A. Effect of 4octylphenol on germ cell number in cultured human fetal gonads. Hum Reprod. 2001, 16, 236-243.

9. Katsuda, S.; Yoshida, M.; Isagawa, S.; Asagawa.; Kuroda, H.; Watanabe, T.; Ando, J.; Takahashi, M.; Maekawa, A. Dose- and treatment duration-related effects of p-tert-octylphenol on female rats. Reprod Toxicol. 2000, 14, 119-126.

10. Kawaguchi, H.; Miyoshi, N.; Miyamoto, Y.; Souda, M.; Umekita, Y.; Yasuda, N.; Yoshida, H. Effects of fetal exposure to 4-n-octylphenol on mammary tumorigenesis in rats. In Vivo. 2010, 24, 463-470.

11. Nagao, T.; Yoshimura, S.; Saito, Y.; Nakagomi, M.; Usumi, K.; Ono, H. Reproductive effects in male and female rats from neonatal exposure to p-octylphenol. Reprod. Toxicol. 2001, 15, 683-692.

12. Bär, P. R. Apoptosis--the cell's silent exit. Life. Sci. 1996, 595, 369-78.

13. Böhm, I.; Schild, H. Apoptosis: the complex scenario for a silent cell death. Mol Imaging. Biol. 2003, 5, 2-14.

14. Edlich, F. BCL-2 proteins and apoptosis: Recent insights and unknowns. Biochem. Biophys. Res. Commun. 2018, 500, 26-34. 
15. Yao, G.; Yang, L.; Hu, Y.; Liang, J.; Liang, J.; Hou, Y. Nonylphenol-induced thymocyte apoptosis involved caspase-3 activation and mitochondrial depolarization. Mol. Immunol. 2006, 43, 915-926.

16. Li, K.; Li, Y.; Shelton, J.M.; Richardson, J.A.; Spencer, E.; Chen, Z.J.; Wang, X.; Williams, R.S. Cytochrome $\mathrm{c}$ deficiency causes embryonic lethality and attenuates stress-induced apoptosis. Cell. 2000, 12, 101, 389-399.

17. Qian, J.; Bian, Q.; Cui, L.; Chen, J.; Song, L.; Wang, X. Octylphenol induces apoptosis in cultured rat Sertoli cells. Toxicol. Lett. 2006, 166, 178-186.

18. Raychoudhury, S.S.; Blake, C.A.; Millette, C.F. Toxic effects of octylphenol on cultured rat spermatogenic cells and Sertoli cells. Toxicol. Appl. Pharmacol. 1999, 157, 192-202.

19. Theodorakis, P.; Lomonosova, E.; Chinnadurai, G. Critical requirement of BAX for manifestation of apoptosis induced by multiple stimuli in human epithelial cancer cells. Cancer. Res. 2002, 62, 3373-3376.

20. Lindsten, T.; Ross, A.J.; King, A.; Zong, W.X.; Rathmell, J.C.; Shiels, H.A.; Ulrich, E.; Waymire, K.G.; Mahar, P.; Frauwirth, K.; Chen, Y.; Wei, M.; Eng, V.M.; Adelman, D.M.; Simon, M.C.; Ma, A.; Golden, J.A.; Evan, G.; Korsmeyer, S.J.; MacGregor, G.R.; Thompson, C.B. The combined functions of proapoptotic Bcl-2 family members bak and bax are essential for normal development of multiple tissues. Mol Cell. 2000, 6, 1389-1399.

21. Green, D.R.; Kroemer, G. The pathophysiology of mitochondrial cell death. Science. 2004, 305, 626629.22 .

22. Jiang, X.; Wang, X. Cytochrome c promotes caspase- 9 activation by inducing nucleotide binding to Apaf-1. J. Biol. Chem. 2000, 275, 1199-1203.

23. Wei, M.C.; Zong, W.X.; Cheng, E.H.; Lindsten, T.; Panoutsakopoulou, V.; Ross, A.J.; Roth, K.A.; MacGregor, G.R.; Thompson, C.B.; Korsmeyer, S.J. Proapoptotic BAX and BAK: a requisite gateway to mitochondrial dysfunction and death. Science. 2001, 292, 727-730.

24. Nimrod, A.C.; Benson, W.H. Environmental estrogenic effects of alkylphenol ethoxylates. Crit. Rev. Toxicol. 1996, 26, 335-364.

25. Li, X.; Liu, J.; Zhang, Y. Octylphenol induced gene expression in testes of Frog, Rana chensinensis. Ecotoxicol. Environ. Saf. 2016, 128, 75-82.

26. Gralén, B.; Visalvethaya, W.; Ljungvall, K.; Tantasuparuk, W.; Norrgren, L.; Magnusson, U. Sows exposed to octylphenol in early gestation: no estrogenic effects in male piglets, but increased rate of stillbirth. Theriogenology. 2012, 78, 1494-1499.

27. Genovese, G.; Da Cuña, R.; Towle, D.W.; Maggese, M.C.; Lo Nostro, F. Early expression of zona pellucida proteins under octylphenol exposure in Cichlasoma dimerus (Perciformes, Cichlidae). Aquat Toxicol. 2011, 101, 175-185.

28. Rey Vázquez, G.; Meijide, F.J.; Da Cuña, R.H.; Lo Nostro, F.L.; Piazza, Y.G.; Babay, P.A.; Trudeau, V.L.; Maggese, M.C.; Guerrero, G.A. Exposure to waterborne 4-tert-octylphenol induces vitellogenin synthesis and disrupts testis morphology in the South American freshwater fish Cichlasoma dimerus (Teleostei, Perciformes). Comp Biochem. Physiol. C Toxicol. Pharmacol. 2009, 150, 298-306.

29. Othman, A.I.; El-Missiry, M.A.; Koriem, K.M.; El-Sayed, A.A. Alfa-lipoic acid protects testosterone secretion pathway and sperm quality against 4-tert-octylphenol induced reproductive toxicity. Ecotoxicol Environ Saf. 2012, 81, 76-83.

30. Gregory, M.; Lacroix, A.; Haddad, S.; Devine, P.; Charbonneau, M.; Tardif, R.; Krishnan, K.; Cooke, G.M.; Schrader, T.; Cyr, D.G. Effects of chronic exposure to octylphenol on the male rat reproductive system. J. Toxicol. Environ. Health A. 2009, 72, 1553-1560.

31. Nikula, H.; Talonpoika, T.; Kaleva, M.; Toppari, J. Inhibition of hCG-stimulated steroidogenesis in cultured mouse Leydig tumor cells by bisphenol A and octylphenols. Toxicol. Appl. Pharmacol. 1999, 151, 166-173.

32. Bian, Q.; Qian, J.; Xu, L.; Chen, J.; Song, L.; Wang, X. The toxic effects of 4-tert-octylphenol on the 
reproductive system of male rats. Food. Chem. Toxicol. 2006, 44, 1355-1361.

33. Griswold, M.D. The central role of Sertoli cells in spermatogenesis. Semin. Cell. Dev. Biol. 1998, 9, 411-416.

34. Boekelheide, K. Mechanisms of toxic damage to spermatogenesis. J. Natl. Cancer. Inst. Monogr. 2005, 34, 6-8.

35. Boekelheide, K.; Fleming, S.L.; Johnson, K.J.; Patel, S.R.; Schoenfeld, H.A. Role of Sertoli cells in injury-associated testicular germ cell apoptosis. Proc. Soc. Exp. Biol. Med. 2000, 225, 105-115.

36. Nair-Menon, J.U.; Campbell, G.T.; Blake, C.A. Toxic effects of octylphenol on cultured rat and murine splenocytes. Toxicol. Appl. Pharmacol. 1996, 139, 437-444.

37. Zumbado, M.; Boada, L.D.; Torres, S.; Monterde, J.G.; Díaz-Chico, B.N.; Afonso, J.L.; Cabrera, J.J.; Blanco, A. Evaluation of acute hepatotoxic effects exerted by environmental estrogens nonylphenol and 4-octylphenol in immature male rats. Toxicology. 2002, 175, 49-62. 